Syria, Tunisia, United Arab Emirates, Republic of Yemen. *Membership suspended since 1993.

Headquarters: PO Box 21923, Safat 13080, Kuwait.

Website: http://www.arabfund.org

Director General and Chairman of the Board of Directors: Abdulatif Y. A1 Hamad.

Publications. Annual Report; Joint Arab Economic Report.

\title{
ARAB MAGHREB UNION
}

The Arab Maghreb Union was founded in 1989 to promote political co-ordination, co-operation and 'complementarity' across various fields, with integration wherever and whenever possible.

Members. Algeria, Libya, Mauritania, Morocco, Tunisia.

By late 1996 joint policies and projects under way or under consideration included: the establishment of the Maghreb Investment and Foreign Trade Bank to fund joint agricultural and industrial projects; free movement of citizens within the region; joint transport undertakings, including railway improvements and a Maghreb highway; creation of a customs union; and establishment of a common market.

A Declaration committing members to the establishment of a free trade zone was adopted at the AMU's last summit in Tunis (April 1994). In Nov. 1992 members adopted a charter on protection of the environment.

Official language: Arabic.

Headquarters: 14 Rue Zalagh, Agdal, Rabat, Morocco.

Website: http://www.maghrebarabe.org

Secretary-General: Habib Boularès (Tunisia).

\section{ARAB MONETARY FUND (AMF)}

Origin. The Agreement establishing the Arab Monetary Fund was approved by the Economic Council of the League of Arab States in April 1976 and the first meeting of the Board of Governors was held on 19 April 1977.

Aims. To assist member countries in eliminating payments and trade restrictions, in achieving exchange rate stability, in developing capital markets and in correcting payments imbalances through the extension of short- and medium-term loans; the co-ordination of monetary policies of member countries; and the liberalization and promotion of trade and payments, as well as the encouragement of capital flows among member countries.

Members. Algeria, Bahrain, Comoros, Djibouti, Egypt, Iraq, Jordan, Kuwait, Lebanon, Libya, Mauritania, Morocco, Oman, Palestine, Qatar, Saudi Arabia, Somalia, Sudan, Syria, Tunisia, United Arab Emirates, Republic of Yemen.

Headquarters: PO Box 2818, Abu Dhabi, United Arab Emirates.

Website: http://www.amf.org.ae

Director General and Chairman of the Board of Directors: Jassim A. Al-Mannai.

Publications (in English and Arabic): Annual Report; The Articles of Agreement of the Arab Monetary Fund; Money and Credit in Arab Countries (annual); National Accounts of Arab Countries (annual); Foreign Trade of Arab Countries (annual); Cross Exchange Rates of Arab Currencies (annual); Arab Countries: Economic Indicators (annual); Balance of Payments and External Public Debt of Arab Countries (annual); AMF Publications Catalogue (annual); Arab Monetary Fund: Structure and Activities (1977-83). (In Arabic only): The Joint Arabic Economic Report (annual); AMF Economic Bulletin; Developments in Arab Capital Markets (quarterly). 